\title{
Front Matter: Volume 8054
}

, "Front Matter: Volume 8054," Proc. SPIE 8054, Enabling Photonics Technologies for Defense, Security, and Aerospace Applications VII, 805401 (17 May 2011); doi: 10.1117/12.899242

SDIE Event: SPIE Defense, Security, and Sensing, 2011, Orlando, Florida, United SPIE. States 


\section{PROCEEDINGS OF SPIE}

\section{Enabling Photonics Technologies for Defense, Security, and Aerospace Applications VII}

Michael J. Hayduk

Peter J. Delfyett, Jr.

Editors

25-26 April 2011

Orlando, Florida, United States

Sponsored and Published by

SPIE

Volume 8054 
The papers included in this volume were part of the technical conference cited on the cover and title page. Papers were selected and subject to review by the editors and conference program committee. Some conference presentations may not be available for publication. The papers published in these proceedings reflect the work and thoughts of the authors and are published herein as submitted. The publisher is not responsible for the validity of the information or for any outcomes resulting from reliance thereon.

Please use the following format to cite material from this book:

Author(s), "Title of Paper," in Enabling Photonics Technologies for Defense, Security, and Aerospace Applications VII, edited by Michael J. Hayduk, Peter J. Delfyett, Jr., Proceedings of SPIE Vol. 8054 (SPIE, Bellingham, WA, 2011) Article CID Number.

ISSN 0277-786X

ISBN 9780819486288

Published by

SPIE

P.O. Box 10, Bellingham, Washington 98227-0010 USA

Telephone +1 3606763290 (Pacific Time) · Fax +1 3606471445

SPIE.org

Copyright (C) 2011, Society of Photo-Optical Instrumentation Engineers

Copying of material in this book for internal or personal use, or for the internal or personal use of specific clients, beyond the fair use provisions granted by the U.S. Copyright Law is authorized by SPIE subject to payment of copying fees. The Transactional Reporting Service base fee for this volume is $\$ 18.00$ per article (or portion thereof), which should be paid directly to the Copyright Clearance Center (CCC), 222 Rosewood Drive, Danvers, MA 01923. Payment may also be made electronically through CCC Online at copyright.com. Other copying for republication, resale, advertising or promotion, or any form of systematic or multiple reproduction of any material in this book is prohibited except with permission in writing from the publisher. The CCC fee code is 0277-786X/11/ \$18.00.

Printed in the United States of America.

Publication of record for individual papers is online in the SPIE Digital Library.

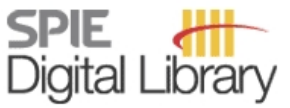

SPIEDigitalLibrary.org

Paper Numbering: Proceedings of SPIE follow an e-First publication model, with papers published first online and then in print and on CD-ROM. Papers are published as they are submitted and meet publication criteria. A unique, consistent, permanent citation identifier (CID) number is assigned to each article at the time of the first publication. Utilization of CIDs allows articles to be fully citable as soon they are published online, and connects the same identifier to all online, print, and electronic versions of the publication. SPIE uses a six-digit CID article numbering system in which:

- The first four digits correspond to the SPIE volume number.

- The last two digits indicate publication order within the volume using a Base 36 numbering system employing both numerals and letters. These two-number sets start with 00, 01, 02, 03, 04, $05,06,07,08,09,0 A, 0 B \ldots 0 Z$, followed by 10-1Z, 20-2Z, etc.

The CID number appears on each page of the manuscript. The complete citation is used on the first page, and an abbreviated version on subsequent pages. Numbers in the index correspond to the last two digits of the six-digit CID number. 


\section{Contents}

$\checkmark \quad$ Conference Committee

\section{PHOTONIC DEVICES AND COMPONENTS}

805404 Theoretical study of spur-free dynamic range of a semiconductor resonant cavity linear interferometric intensity modulator (Invited Paper) [8054-02]

N. Hoghooghi, P. J. Delfyett, CREOL, The College of Optics and Photonics, Univ. of Central Florida (United States)

805406 Large scale micro-Fabry-Perot optical filter arrays [8054-04]

A. A. Abtahi, Aerospace Missions Corp. (United States); P. B. Griffin, Stanford Univ. (United States); R. J. Morgan, U. Raghuram, F. S. Vetelino, Aerospace Missions Corp. (United States); F. Tejada, Sensing Machines (United States)

\section{VCSELS AND QUANTUM DOTS}

8054 OA New VCSEL technology with scalability for single mode operation and densely integrated arrays [8054-08]

G. Zhao, CREOL, The College of Optics and Photonics, Univ. of Central Florida (United States); A. Demir, S. Freisem, CREOL, The College of Optics and Photonics, Univ. of Central Florida (United States) and sdPhotonics LLC (United States); Y. Zhang, X. Liu, CREOL, The College of Optics and Photonics, Univ. of Central Florida (United States); D. G. Deppe, CREOL, The College of Optics and Photonics, Univ. of Central Florida (United States) and sdPhotonics LLC (United States)

\section{ULTRASHORT PULSED LASERS AND OPTICAL SWITCHING}

8054 OC Injection locked coupled opto-electronic oscillator for optical frequency comb generation [8054-10]

C. Williams, D. Mandridis, J. Davila-Rodriguez, P. J. Delfyett, CREOL, The College of Optics and Photonics, Univ. of Central Florida (United States)

8054 OE Design of cascaded plasmon resonances for ultrafast nonlinear optical switching [8054-12] S. Toroghi, CREOL, The College of Optics and Photonics, Univ. of Central Florida (United States); P. G. Kik, CREOL, The College of Optics and Photonics, Univ. of Central Florida (United States) and Univ. of Central Florida (United States)

\section{EMITTER AND DETECTOR TECHNOLOGY}

8054 OG An etalon stabilized 10-GHz comb source using a slab coupled waveguide amplifier [8054-14]

J. Davila-Rodriguez, I. T. Ozdur, D. Mandridis, C. Williams, P. J. Delfyett, CREOL, The College of Optics and Photonics, Univ. of Central Florida (United States); J. J. Plant, P. W. Juodawlkis, MIT Lincoln Lab. (United States) 
8054 Ol Semiconductor-based low-noise $100 \mathrm{MHz}$ chirped pulse laser source based on a theta cavity design with an intra-cavity etalon and long-term stabilization (Invited Paper) [8054-16]

D. Mandridis, C. Williams, I. Ozdur, A. Klee, P. J. Delfyett, CREOL, The College of Optics and Photonics, Univ. of Central Florida (United States)

8054 OK 25 Gbps 850 nm photodiode for emerging 100 Gb ethernet applications (Invited Paper) [8054-18]

A. Joshi, J. Rue, D. Becker, S. Datta, W. McFaul, Discovery Semiconductors, Inc. (United States)

\section{OPTICAL COMMUNICATION SYSTEMS AND TECHNOLOGY I}

8054 OL Free-space optical communication link using spatial optical encryption [8054-20] S. H. Murshid, W. Howard, Florida Institute of Technology (United States); N. R. Murshid, Sebastian River Medical Ctr. (United States); A. Chakravarty, Florida Institute of Technology (United States)

8054 OM Optical encryption as a function of polarization in optical fiber communications [8054-21] S. H. Murshid, H. P. Muralikrishnan, J. Tamilarasan, A. Chakravarty, Florida Institute of Technology (United States); H. J. Caulfield, Alabama A\&M Univ. (United States) and Diversified Research Corp. (United States)

8054 ON A method of hardware support for high-speed data capture at $\mathbf{4 0}$ Gbps and beyond [8054-22]

J. S. White, Secure Mind Research Lab. (United States); A. W. Pilbeam, Pilbeam Engineering (United States)

\section{OPTICAL COMMUNICATION SYSTEMS AND TECHNOLOGY II}

805400 An analysis of coupling attacks in high-speed fiber optic networks [8054-23] J. S. White, Secure Mind Research Lab. (United States); A. W. Pilbeam, Pilbeam Engineering (United States)

8054 OP Attenuation and bit error rate for four co-propagating spatially multiplexed optical communication channels of exactly same wavelength in step index multimode fibers [8054-24]

S. H. Murshid, A. Chakravarty, Florida Institute of Technology (United States)

\section{POSTER SESSION}

8054 OR Mode-locked fiber laser using SU8 resist incorporating carbon nanotubes [8054-26] I. Hernandez-Romano, Instituto Nacional de Astrofísica, Óptica y Electrónica (Mexico); D. Mandridis, CREOL, The College of Optics and Photonics, Univ. of Central Florida (United States); D. A. May-Arrioja, Univ. Autónoma de Tamaulipas (Mexico); J. J. Sanchez-Mondragon, Instituto Nacional de Astrofísica, Óptica y Electrónica (Mexico); P. J. Delfyett, CREOL, The College of Optics and Photonics, Univ. of Central Florida (United States) 
8054 OS Impairment compensation for unrepeatered fiber transmission with distributed Raman amplification [8054-27]

L. Zhu, G. Li, CREOL, The College of Optics and Photonics, Univ. of Central Florida (United States)

8054 OT Description of various test scenarios for temporary blinding of pilots by means of bright optical radiation during darkness [8054-28]

H.-D. Reidenbach, Cologne Univ. of Applied Sciences (Germany)

Author Index 
Downloaded From: https://www.spiedigitallibrary.org/conference-proceedings-of-spie on 26 Apr 2023

Terms of Use: https://www.spiedigitallibrary.org/terms-of-use 


\title{
Conference Committee
}

\author{
Symposium Chair
}

William Jeffrey, HRL Laboratories, LLC (United States)

Symposium Cochair

Kevin P. Meiners, Office of the Secretary of Defense (United States)

Conference Chairs

Michael J. Hayduk, Air Force Research Laboratory (United States)

Peter J. Delfyett, Jr., CREOL, The College of Optics and Photonics, University of Central Florida (United States)

Conference Cochairs

Andrew R. Pirich, ACP Consulting (United States)

Eric Donkor, University of Connecticut (United States)

Program Committee

H. John Caulfield, Diversified Research Corporation (United States)

Reinhard K. Erdmann, Air Force Research Laboratory (United States)

Michael L. Fanto, Air Force Research Laboratory (United States)

Sangyoun Gee, Gwangju Institute of Science and Technology (Korea, Republic of)

Bahram Javidi, University of Connecticut (United States)

Robert L. Kaminski, Air Force Research Laboratory (United States)

Guifang Li, CREOL, The College of Optics and Photonics, University of Central Florida (United States)

Joseph M. Osman, Air Force Research Laboratory (United States)

Edward W. Taylor, International Photonics Consultants, Inc. (United States)

Henry Zmuda, University of Florida (United States)

Session Chairs

Keynote Session

Eric Donkor, University of Connecticut (United States)

Photonic Devices and Components

Michael J. Hayduk, Air Force Research Laboratory (United States) 
VCSELS and Quantum Dots

Peter J. Delfyett, Jr., CREOL, The College of Optics and Photonics,

University of Central Florida (United States)

Ultrashort Pulsed Lasers and Optical Switching

Michael L. Fanto, Air Force Research Laboratory (United States)

Emitter and Detector Technology

Guifang Li, CREOL, The College of Optics and Photonics, University of Central Florida (United States)

Optical Communication Systems and Technology I

Peter J. Delfyett, Jr., CREOL, The College of Optics and Photonics, University of Central Florida (United States)

Optical Communication Systems and Technology II

Michael J. Hayduk, Air Force Research Laboratory (United States) 